\title{
THE BRITISH MEDICAL PROFESSION AND CONTAGION THEORY: PUERPERAL FEVER AS A CASE STUDY, 1830-1860
}

\author{
by
}

\section{GAIL PAT PARSONS*}

AFTER EXAMINING the reactions of physicians to sporadic, socially disruptive epidemics of cholera, yellow fever, and the plague, historians have concluded that "anticontagionism" characterized medical thought in the first half of the nineteenth century. ${ }^{1}$ That conclusion is not borne out by this study. It is true that well-known figures confronted with the task of explaining the capricious visitations of pandemic diseases rejected the theory of contagion. When attention is directed away from both the atypical disease and the eminent physician, a somewhat different attitude emerges toward "contagionism". Puerperal fever, a septic infection common to parturient women in the nineteenth century, was "a disease in which the proportion of deaths to recoveries far exceed[ed] that of malignant cholera. ..."2 Monotonous epidemics of this disease haunted physicians and provoked them into a sustained discussion over its contagiousness. By focusing, for the most part, on now forgotten practitioners and their response to an endemic disease, this study reveals that doctors who lost a succession of women to puerperal fever formed a saddened "contagionist" vanguard.

Mid-nineteenth-century discussions regarding the contagiousness of puerperal fever took place within a context of animated professional rivalries and therapeutic uncertainties. The medical profession retained its hierarchical structure, a remnant of the medieval guild system. Physicians enjoyed more prestige than either apothecaries or surgeons, the latter being considered mere "cutters for stone". ${ }^{3}$ Nevertheless, each group shared a common concern: the spread of disease. The profession

*Gail Pat Parsons, M.A., 1596 Euclid, Berkeley, California 94708, U.S.A.

1 For a sympathetic evaluation of the "anticontagionists" see Charles-Edward A. Winslow, The conquest of epidemic disease, Princeton, Princeton University Press, 1943, especially p. 182; Erwin H. Ackerknecht, 'Anticontagionism between 1821 and 1867', Bull. Hist. Med., 1948, 22: 562-593. Charles E. Rosenberg documents the widespread rejection of contagion theory in America in his The cholera years, Chicago, University of Chicago Press, 1962, especially pp. 76-79, 165. See also Richard H. Shryock, Medicine and society in America: 1660-1860, Ithaca, Cornell University Press, 1962, p. 63; George Rosen, $A$ history of public health, New York, MD Publications Inc., 1958, pp. 289-290; Phyllis Allen, 'Etiological theory in America prior to the civil war', J. Hist. Med., 1947, 2: 489-520.

' Robert Storrs, 'Observations on puerperal fever', Prov. Med. J. and Retrosp. Med. Sci., 1843, 7: 163-169, p. 167.

'W. J. Reader, Professional men: the rise of the professional classes in nineteenth century England, New York, Basic Books, 1966, especially pp. 16-21. 


\section{British medical profession and contagion theory: puerperal fever 1830-1860}

had failed to prevent some 50,000 deaths during the 1832 cholera epidemic, while endemic febrile diseases just as deadly though less spectacular confounded doctors. Overcrowded and unsanitary hospitals had become "forcing houses for sepsis".4 Puerperal fever, erysipelas, and gangrene ran rampant through wards where pregnant women shared beds with infected patients. All practitioners, regardless of status, recognized their helplessness against epidemic disease.

The uncertainty permeating the profession by the 1830 s should be viewed in part as a reaction to disappointing legacies. Throughout the late eighteenth century and until the political revolutions of 1848 , French discoveries that certain diseases were specific entities generated hope that scientific methods would perfect medicine. ${ }^{5}$ An unrelenting commitment to dissection as the key to locating the seat of all human ailments, while a step forward over imprecise chemical and mechanical explanations, eventually produced much the same havoc as earlier attempts to classify disease strictly by observable symptoms. ${ }^{6}$ Post-mortems often revealed what appeared to examiners as contradictory evidence. Puerperal fever, for example, defied specific identification.

Xavier Bichat (1771-1802), an innovative force at the Paris Hospital, after performing numerous autopsies, believed that all disease originated at the tissue or membrane level. Based on his discovery of peritoneal lesions in women who had supposedly died of puerperal fever, Bichat concluded that this disease was no longer another mysterious fever but a specific disease-peritonitis. Meanwhile, doctors found simultaneous lesions in the peritoneum and uterus, two completely different types of tissue. Later autopsies revealed inflamed uterine veins and inflamed lymph vessels. After subsequent investigations located the presence of pus and the total absence of specific tissue lesions, some French practitioners declared puerperal fever a purulent or pus-producing disease, an explanation that suggested that the seat of the disease lay in the cells and not in the tissues as Bichat supposed. Scientific methods had proved that puerperal fever could be either a tissue-level inflammatory disease or a more systemic disorder. The practitioner of $1830 \mathrm{had}$ gained one advantage over earlier colleagues-science had legitimized his confusion about puerperal fever. ${ }^{7}$

Hard pressed to explain the origin and spread of any disease and endemic febrile diseases in particular, an eighteenth-century theory remained useful. William Cullen

- Wyndham E. B. Lloyd, A hundred years of medicine, 2nd ed., London, Duckworth, 1968, p. 33.

' Erwin H. Ackerknecht, Medicine at the Paris hospital, 1794-1848, Baltimore, Johns Hopkins Press, 1967, pp. 94-96.

- By 1789, François Boissier de Sauvages had identified no fewer than 2,400 "diseases" by interpreting each symptomatic variation of an illness as a distinctly different disease. See the classic, Knud Faber, Nosography in modern internal medicine, New York, Paul B. Hoeber, 1922, pp. 20-25.

7 An American aptly summed up the confusion. See Samuel Kneeland, 'On the contagiousness of puerperal fever', Am. J. med. Sci., 1846, 11: 45-63, p. 46.

Puerperal sepsis is the result of a genital tract infection. Infective organisms usually enter through a lesion in the mucous membrane received during the process of childbirth. Passage of the foetus through the uterine cervical mouth and the birth canal, along with separation of the placenta, leaves the entire area raw, making it in effect, an "open wound". Open blood vessels invite bacterial invasion, and a single streptococcal species can produce a variety of diseases. Genital tract infection can result in, for instance, peritonitis, pyaemia, or lymphangitis. Any of these complications can prove fatal. With only a primitive understanding of disease processes, it is understandable that physicians were bewildered by puerperal fever which manifests itself in unpredictable forms. 


\section{Gail Pat Parsons}

(1710-1790), an influential Edinburgh physician, had theorized that when fevers assumed an "epidemic character", the remote cause could be traced to "some matter floating in the atmosphere". He divided this inanimate matter into two categories. A person afflicted with a recognizable disease such as smallpox gave off "contagions" which then produced smallpox in all persons exposed to them. The second kind of inanimate matter Cullen labelled "miasmata". Miasmata emanated from a non-human source such as swampy ground and produced not one but a variety of febrile diseases including typhoid, yellow fever, and malaria (mal aria, "bad air"). Since Cullen had previously reduced the causes of all disease to either an excess or lack of nervous energy, the addition of the contagion-miasmata theory to explain the spread of disease completed his so-called medical "system"."

Hoping to release themselves from what they interpreted as the speculative, dogmatic "systems" of the preceding century, nineteenth-century practitioners had subtly obscured the distinction made by Cullen between inanimate human contagions and inanimate non-human miasmata. Miasm, they theorized, could emanate from humans as well as from rural swamps or stinking urban cesspools. A British physician painted a vivid picture of this idea when he suggested in the early part of the century that "if any person [took] the trouble to stand in the sun and look at his shadow on a white plastered wall, he [would] easily perceive that his whole body is a smoking dunghill, with a vapor exhaling from every part of it." Logic led this doctor to conclude that disease could engulf people confined together in poorly ventilated spaces and who were forced to breathe or "swallow with their spittle the vapors of each other". Airborne transfer of a noxious miasm explained to contemporaries the origin, persistence, and spread of contagious diseases in prisons, ships, and hospitals.

By the 1830s, hospitals were rarely free of septic disease. These institutions revealed in microcosm the unsanitary conditions that existed throughout Great Britain. Filth, overcrowding, and squalor were the hallmarks of rural village and urban area. Infectious diseases were commonplace but, according to one observer, puerperal fever found its "greatest perfection" in lying-in hospitals. ${ }^{10}$ This was a gloomy appraisal of buildings that had originally held the promise of significant advances for the practice of obstetrics.

During the latter part of the eighteenth century when men assumed control of midwifery, demands for male obstetrical services and the need for clinical teaching facilities led to the creation of lying-in hospitals. ${ }^{11}$ The entrance of males into this historically defined "woman's work" reflected an attitudinal change in patient as

- William Cullen, First lines on the practice of physic, new ed., 4 vols., Edinburgh, 1786, vol. 1, pp. xli-xlii; quoted in Lester S. King, The medical world of the eighteenth century, Chicago, University of Chicago Press, 1958, p. 141.

- Quoted in Winslow, op. cit., note 1 above, p. 239, note.

10 W. T. Boddy, 'Notes on puerperal fever', Br. Rec. Obstet. med. Surg., 1848, 1: 339-347, p. 341. Similar comments can be found in Matthew Gibson, 'Puerperal fever', Lancet, 1842, ii: 121-129, p. 123; Seth Thompson, 'On puerperal diseases', Lond. Med. Gaz., 1838, 22: 181-185, p. 182; Edward Blackmore, 'Observations on the nature, origin, and treatment of puerperal fever', Prov. Med. Surg. J., 1845, 9: 173-178, p. 173; William Faussett, 'An essay on puerperal fever, with suggestions for improved methods of treatment', Dublin quart. J. med. Sci., 1850, 9: 286-309, p. 286.

${ }^{11}$ Alistair Gunn, 'Maternity hospitals', in F. N. L. Poynter (editor), The evolution of hospitals in Britain, London, Pitman Medical Publishing Co., 1964, pp. 77-101. 


\section{British medical profession and contagion theory: puerperal fever 1830-1860}

well as in practitioner. Male ascendancy over the female midwife was enhanced by their access to the forceps. This instrument, especially useful in shortening difficult labour, enjoyed a zealous welcome from the men who used it and from grateful women. ${ }^{12}$ Positive, if not universal, acceptance of male midwives encouraged surgeons with a need for anatomical knowledge to seek instruction in obstetrics. ${ }^{13}$ Lying-in hospitals intended as teaching centres ironically fulfilled their promise. They ensured that the profession learned first-hand about epidemic puerperal fever. ${ }^{14}$ By 1850 , deplorable maternal mortality rates within these institutions suggested to one physician that hospitals had become "the gates which lead [women] to death". ${ }^{15}$

Hospitals seemed to yield ample evidence of the connexion between human miasm and disease. It appeared to observers that a congregation of recently delivered females (sometimes two or three to a bed) could "manufacture puerperal fever at will".16 Women were delivered in the same room where other women recovered from or awaited childbirth. Their bloody discharges filled the air with noxious smells, an "animal miasmata", which doctors likened to the foul vapours emanating from

12 James Hobson Aveling, The Chamberlens and the midwifery forceps, London, Churchill, 1882. See also William Goodell, 'When and why were male physicians employed as accoucheurs?', Am. J. Obstet., 1876, 9: 381-390; William F. Mengert, 'The origin of the male midwife', Ann. med. Hist., 1932, 4: 453-464; H. J. Malkin, 'The rise of obstetrics in British medical practice and the influence of the royal college of obstetricians and gynaecologists', in F. N. L. Poynter (editor), The evolution of medical practice in Britain, London, Pitman Medical Publishing Co., 1961, pp. 57-65.

13 Gunn, op. cit., note 11 above, pp. 77-78.

14 Fleetwood Churchill (editor), Essays on the puerperal fever and other diseases peculiar to women, London, Sydenham Society, 1849, p. 32. See also Cecilia C. Mettler, History of medicine, Philadelphia, Blakiston Company, 1947, p. 965; J. B. Fleming, 'Puerperal fever: the historical development of its treatment', Proc. R. Soc. Med., 1966, 59: 341-345, p. 341.

13 Thomas Lightfoot, 'Some practical observations on the disease usually called puerperal fever', Lond. med. Times, 1850, 21 : 463-465, p. 464.

Thomas McKeown and R. J. Brown ignited a debate among historians of medicine when in $\mathbf{1 9 5 5}$ they suggested that medical practice contributed little to the reduction in mortality that took place in the eighteenth century. 'Medical evidence related to English population changes in the eighteenth century', Popul. Stud., 1955, 9: 119-141. E. M. Sigsworth surveyed the records and reports of a county hospital and concluded that hospitals were not "gateways to death" and that medical care had improved. 'Gateways to death? medicine, hospitals and mortality, 1700-1850', in Peter Mathias (editor), Science and Society, 1600-1900, Cambridge University Press, 1972, pp. 97-110. J. H. Woodward agreed with Sigsworth's evaluation. See his 'Before bacteriology-deaths in hospitals', Yorks Fac. J., 1969, autumn, 15-26. F. F. Cartwright also stated that hospitals were relatively safe. He noted that only six per cent of the surgical patients died of infection; and he blamed this mortality on "dirty" patients, not "dirty" surgeons. 'Antiseptic surgery', in F. N. L. Poynter (editor), Medicine and society in the 1860s, London, Pitman Medical Publishing Co., 1968, pp. 77-103. Kenneth Keele, in contrast, argued that hospital mortality increased because operations performed under septic conditions increased the risks of septic infections. 'Clinical medicine in the 1860s', in ibid., pp. 1-11.

While McKeown and Brown specifically mentioned the risks to hospitalized pregnant and parturient women, the other historians practically ignored the issue. The dismal mortality rate among women has thus been casually dismissed. This study implicitly calls attention to those women. See the impressive statistical account of the Registrar-General's Records by W. P. D. Long. He found that from 1848 to 1872, diseases from maternal causes (including sepsis) killed ten per thousand women (based on total population). 'Mortality in England and Wales from 1848 to 1947', Popul. Stud., 1950, 4: 132-178. Given the diagnostic uncertainties, it is likely that the returns are too low. See the contemporary comment by Edward Murphy, 'Puerperal fever', Dublin quart. J. med. Sci., 1857, 24: 1-30, pp. 2-3.

16 James Young Simpson, Selected obstetrical and gynecological works, ed. J. Watt Black, New York, D. Appleton and Co., 1871. Simpson had presented this information twenty years earlier in 1851. 


\section{Gail Pat Parsons}

debris-filled streets, a "civic miasmata".17 Physicians theorized that a woman weakened by the rigours of labour and childbirth was especially susceptible or predisposed to the ill effects of any morbific effluvia.

According to contemporary thought, inhalation of a noxious stench could trigger the ominous sudden chills that signalled the onset of child-bed fever. Once the disease established itself within a particular woman, doctors, unable completely to free themselves from the past, assumed that the infected female exuded a specific contagion capable of then producing puerperal fever in any or all of her ward-mates. ${ }^{18}$ This explanation, so reminiscent of Cullen's contagion-miasmata theory, seems to have answered at once how diseases originated and how they spread, two of the criteria that the historian Charles-Edward A. Winslow has suggested were not only missing but necessary before the medical profession could accept contagion theory. ${ }^{19}$

Technological advances aggravated the incidence of septic disease within hospital confines. After the introduction of anaesthesia in the 1840s and the subsequent increase in surgical operations, wound infection presented surgeons with their greatest dilemma. "Surgical fever" generally accompanied any operation, then the fiery red rash of erysipelas often developed, followed by wound suppuration. Surgery performed under septic conditions promoted streptococcal infection. "Hospital throat" plagued medical attendants. The result of a streptococcal infection, hospital throat, is "both the cause and result of septicemia". ${ }^{20}$ Droplet infection spread disease from surgical patient to lying-in woman, while contaminated dressings, instruments, and hands directly inoculated pathogenic organisms into wounded surfaces. Practitioners who had no faith in the concept of a biological, disease-producing agent, held "bad air" responsible for the deadly epidemics that decimated their hospitalized patients.

When doctors conceded the importance of contaminated air, they were presented, at the same time, with the unhappy possibility that they could transmit disease to lying-in women. The poisonous effluvia, easily recognizable because of the stench, emanating from a woman with puerperal fever could conceivably cling to doctors' clothing, instruments, and even their hands. The perceived ability of this non-living effluvia to cause disease prompted a physician in 1843 to announce that he "would rather a friend or relation of mine was delivered in a stable without assistance, than she should be attended by a practitioner who had just attended a puerperal fever patient". ${ }^{21}$ This comment illuminates the increasing concern among doctors that they carried with them an inanimate, contagious "something, call it what you please". ${ }^{22}$

While tracing a discernible pattern of contamination was impossible in an overcrowded hospital where surgeons and doctors travelled from ward to ward treating endemic septic disesaes, doctors who endured epidemics of puerperal fever in their private practice were not blessed with such anonymity. In 1842, for example, Robert Storrs reported that from 8 January through 26 February 1841, he attended twenty-

${ }_{17}$ Alfred Hudson, Lectures on the study of fever, Philadelphia, Henry C. Lea, 1869, p. 49.

${ }^{18}$ Simpson, op. cit., note 16 above, pp. 513-514; Churchill, op. cit., note 14 above, p. 38; Boddy, op. cit., note 10 above, p. 341.

io Winslow, op. cit., note 1 above, p. 182.

${ }^{20}$ Cartwright, op. cit., note 15 above, p. 86.

${ }^{21}$ N. B. Fisher, 'Malignant puerperal fever', Lond. prov. med. J., 1843, 7: 83-93, p. 92.

22 Amicus Candoris, 'Propagation of puerperal fever', Prov. med. J. Retrosp. med. Sci., 1842, $2: 107$. 


\section{British medical profession and contagion theory: puerperal fever 1830-1860}

four women in labour. Of these twenty-four women, six had died of puerperal fever. After losing the first three patients and before proceeding with obstetrical duties, Storrs "changed [his] clothes, and used every means . . . to prevent . . . spread" of the disease to other patients. He repeated his precautions after each successive case of puerperal fever. When his patients continued to die, desperation forced him to abandon his practice. He left the area hoping that an extended trip would free him "from the poison, which [he] could not now but suppose clung to [him]." Upon his return, he attended two women in labour. Both women, after exhibiting the "usual symptoms" of puerperal fever, died. ${ }^{23}$

Ruminating on the tragic loss of these female patients, Storrs, a now-forgotten Doncaster surgeon, recalled that immediately prior to attending the first fatal case of puerperal fever, he had treated another patient with "gangrenous erysipelas of the leg". Periodically, between attending his obstetrical patients, Storrs returned to open and drain the multiple abscesses, some of which contained "more than a washhand basinful" of offensive-smelling pus. Although he had taken "every pain to prevent the conveyance of the contagion", Storrs concluded that he had carried the "fomes of [erysipelas] to every one of the [dead women]". He urgently warned fellow practitioners to exercise "great precaution" if they continued their obstetrical visits while attending patients with erysipelas. His melancholy confession added Storrs' voice to the growing number of practitioners who believed that transference of the "miasma of erysipelas" could produce puerperal fevers in parturient women. ${ }^{24}$

Motivated by what he described as a "lively and painful interest" in puerperal fever, Storrs had submitted a series of questions about the disease to four of his friends. Results of this casual survey appeared in 1843, and the responses were to the point. All four men surveyed agreed that puerperal fever was contagious and that a connexion existed between it and erysipelas. Three of the respondents admitted that by carrying the contagion of erysipelas they had been instrumental in causing the deaths of their childbed patients. Aware that the disease tracked only himself and his patients, a distressed surgeon who had lost five women to the disease in almost as many days wrote, "I had very strong suspicions that I . . conveyed the infection". ${ }^{25}$ To confirm the conclusions reported by Storrs and possibly encouraged by a sense of shared experience, other practitioners publicly passed similar judgements upon themselves.

In a paper read to the Edinburgh Medico-Chirurgical Society and subsequently published in 1846, Alexander Peddie unburdened himself before colleagues feeling "assured of obtaining sympathy on account of the painful situation in which [he had] been placed". Peddie proceeded to recount the case histories of several women

${ }^{23}$ Robert Storrs, 'History of a puerperal fever in Doncaster', ibid., 1842, 55: 45-51, pp. 48-49.

24 Ibid., pp. 48-49. Storrs is the subject of one historian's interest. See Anne Elizabeth Caldwell, 'The history of puerperal sepsis-corrigendum', J. Obstet. Gynaec. Br. Empire, 1951, 58: 926-929. Storrs' analysis reflected the assumption that exanthematous diseases developed a "gaseous state', (vapours supposedly given off by skin eruptions) which then exerted a morbific influence on the atmosphere. Naturally, such contaminated air could settle on the attending physician.

${ }^{26}$ Storrs, op. cit., note 2 above, pp. 163-165. Two other doctors wrote to confirm Storrs' opinion. See Francis Elkington, 'Observations on the contagiousness of puerperal fever, and its connection with erysipelas', Prov. med. J. Retrosp. med. Sci., 1844, 7: 287; Candoris, op. cit., note 22 above, p. 107. 


\section{Gail Pat Parsons}

he had attended and lost to puerperal fever. After the first two fatalities occurred, he took "every possible precaution ... to prevent ... further transmission" of the disease. The disease continued to stalk him and his patients. After reflecting on the "progress of events", Peddie recalled that prior to the first outbreak of puerperal fever, he treated a "most malignant" and ultimately fatal case of erysipelas. He believed that the epidemic of puerperal fever was intimately related to the patients with erysipelas. He admonished his audience to forego attending patients in childbed while treating any person with erysipelas. If, after doctors exercized every possible precaution, they met with a second case of puerperal fever, they should, in Peddie's opinion, "abandon the practice of midwifery". ${ }^{26}$

Erysipelas and puerperal fever are the result of a streptococcal infection. Both diseases are characterized by a profound toxaemia and both exhibit cellulitis, a marked reddish discoloration of the cutaneous and subcutaneous tissue. To nineteenth-century practitioners dependent upon symptom-based diagnoses, the "erysipelatous appearance of a dusky, red colour, on the knuckles, elbows, knees, or ankles" of a childbed woman was a cause for serious alarm. ${ }^{27}$ The experience of another surgeon typified this concern. After treating the erysipelatous abscesses of a patient, he attended a woman in the final stages of labour. The urgency of the situation prevented him from changing his clothes to "rid himself of miasma", but he removed his coat as a precautionary measure. Twenty-four hours after being delivered, "symptoms of puerperal peritonitis, of the lowest character" seized the woman. She died within the week. A maid who had attended the victim suddenly suffered an ominous shivering fit and, five days later, followed her mistress to the grave. ${ }^{28}$ The evidence seemed to substantiate that puerperal fever and erysipelas were "capable of producing each other". ${ }^{29}$

The perceived transmutability of these diseases had been used to explain their simultaneous appearance in hospitals; now it alerted practitioners to their possible "carrier" role. ${ }^{30}$ Doctors felt responsible for the fatal outcomes of their visits. It is

\footnotetext{
${ }^{26}$ Alexander Peddie, 'Cases illustrative of the contagious nature of puerperal fever, and its intimate connection with erysipelas and phlebitic inflammation', Edinb. med. surg. J., 1846, 65: 77-95, pp. 78, $81,94$.

${ }^{27}$ Thomas Denman, an eighteenth-century practitioner, had recognized this phenomenon. See 'An essay on the puerperal fever', in Churchill, op. cit., note 14 above, pp. 43-60, 48. Mettler notes that the "conceptual association between puerperal fever and erysipelas dates back to Hippocratic times" (op. cit., note 14 above, p. 967).

${ }^{28}$ This was one of many stories related to and reported by Storrs. Robert Storrs, 'On the contagious effects of puerperal fever on the male subject; or on persons not child-bearing', Am. J. med. Sci., 1846, 11: 245-258, p. 246. See also Francis H. Ramsbotham, 'Lectures on the morbid affections of the puerperal and pregnant states', Lond. med. Gaz., 1835, 16: 129-137, p. 130; Gibson, op. cit., note 10 above, p. 123; James Reid, 'Puerperal fever-death of a husband from somewhat analogous symptoms', Am. J. med. Sci., 1846, 11: 516.

29 Samuel Beecroft, 'Illustrations of the contagious nature of puerperal fever', Lancet, 1848, ii: 648-685, p. 685; Thomas West, 'Observations on some diseases, particularly puerperal fever', Lond. med. Reposit., 1815, 3: 104-105; J. Symonds, 'Puerperal fever', Lancet, 1845, i: 553-554, p. 554; R. Yates Ackerly, 'Remarks on the nature and treatment of puerperal fever', Lond. med. Gaz., 1838, 22: 463-466, p. 465.

so Winslow writes "... until to [the theory of living germs] were added the concepts of .... above all, ... human carriers-the hypothesis of contagion simply would not work." op. cit., note 1 above, p. 182.
} 


\section{British medical profession and contagion theory: puerperal fever 1830-1860}

conceivable, for instance, that the maid, who incidentally had an inflamed cut on her hand, could have introduced pathogenic organisms into the pregnant woman. Or, it is possible that the mistress herself harboured infective agents within her vaginal flora, in which case she could have infected the cut on her maid's hand. Even today the designation of a source remains a difficult determination because the organism responsible for streptococcal infection is ubiquitous. ${ }^{81}$ Ignorant of this knowledge, practitioners sadly labelled themselves "vehicles of contagion". 32

Doctors had by the 1840 s recognized a connexion between puerperal fever and overcrowded hospitals, between puerperal fever and erysipelas, and between puerperal fever and themselves, yet they had not introduced anything substantially new to an understanding of the disease or its transmission. Practitioners in the previous century had recognized the identical phenomena. ${ }^{33}$ What has appeared to historians as a unique contribution to the etiology of puerperal fever in the nineteenth century also had intellectual roots in the past. ${ }^{34}$

Given the universal belief in the human origins of a disease-producing miasmata, it is not surprising that doctors questioned the propriety of exposing themselves to the noxious stench given off by a decomposing corpse. The notion that corpses produced disease was not a new idea. It had survived since the seventeenth century when the Jesuit priest, Athanasius Kircher (1622-1680), mentioned the possibility in his plague tract published in 1658. Kircher had seen "animalculae" through a primitive microscope, and he wrote that "small, living animals invisible to the naked eye" spread contagious diseases. Specifically, the effluvia from a decomposing corpse contained contagious elements, "corpuscular" in nature. Kircher theorized that "innumerable imperceptible worms" escaped from the cadaver as it decomposed

21 David Charles and Thomas A. Klein, 'Postpartum infection', in David Charles and Matthew Finland (editors), Obstetric and prenatal infections, Philadelphia, Lea \& Febiger, 1973, pp. 247-272. It was not until 1935 that Dora C. Colebrook, an English physician, illuminated the multiple means of communication. The source of infection in puerperal fever due to haemolytic streptococci, Special report series, no. 205 of Medical Research Council, London, His Majesty's Stationery Office, 1935. In 1965, doctors discovered a previously ignored source of contamination during an outbreak of sepsis that claimed the life of a female post-operative patient. See Donald M. McIntyre, 'An epidemic of streptoccus pyogenes-puerperal and post-operative sepsis with an unusual carrier site-the anus', Am. J. Obstet. Gynec., 1968, 101: 308-313. The organism was traced to an attendant.

22 Edward Hughes, 'On puerperal fever', Prov. med. surg. J., 1850, 13: 428. See also Storrs, op. cit., note 23 above, p. 50.

2s Churchill, op. cit., note 14 above. This anthology contains essays written entirely by eighteenthcentury physicians.

"4 I am referring, of course, to Ignaz Semmelweis. His story is well known and does not bear repeating in detail here. Suffice to say that he demonstrated in 1847 at the Vienna Allgemeines Krankenhaus that when students washed their hands in chlorinated water after attending autopsies and before attending childbirths, the maternal mortality rates dropped. The most recent interpretation of this incident is Owen $\mathbf{H}$. Wangensteen, "Nineteenth-century wound management of the parturient uterus and compound fracture: the Semmelweis-Lister priority controversy', Bull. N. Y. Acad. Med., 1970, 46: 565-590. That Semmelweis' practice saved scores of female lives is obvious, and it is not the purpose of this study to deprecate his accomplishment. It is my contention that the contemporary reaction to his exhortations cannot be adequately assessed if opposition from the rank-and-file doctors is ignored.

More to the point for this study is Semmelweis' "anticontagionism", an aspect of his theory that has elicited few comments from historians. The notable exceptions are Mettler, op. cit., note 14 above, p. 976; Ackerknecht, op. cit., note 1 above, p. 582; Tiberius V. Gyory, 'Oliver Wendell Holmes and Semmelweis', Br. med. J., 1906, ii: 715-716. 


\section{Gail Pat Parsons}

and created a "living effluvium" that could be breathed in or "transmitted by the fingers or other forms of contact". 35

Nineteenth-century practitioners ignored what they considered Kircher's medieval, speculative idea of a living effluvium while embracing his notion that a dead body could give off fever-producing "putrid effluvium". One doctor, in fact, held "necropsical examinations" totally responsible for the origins of puerperal fever. He wrote in 1831 that "unless a practitioner [is] engaged in dissection, .... [puerperal fever] cannot be conveyed by him." An Another physician blamed surgeons for propagating the disease. He accused his professional rivals of inoculating their female patients with the lethal effluvia derived from the corpses they so zealously examined. Insufficient precautions, he went on, led to the unnecessary deaths of many women. ${ }^{37}$ Ruinous competition for prestige and patronage exacerbated the tension among members of a segregated profession. The willingness of one practitioner to accept responsibility for the spread of puerperal fever was countered by an equal willingness to pinpoint the blame on a competitor. In either event, the idea that puerperal fever was contagious and that attendants were intimately involved in its transmission is apparent.

By itself, the desire to protect professional reputations does not fully explain the attitudes toward autopsies. The findings of such examinations had not minimized the confusion surrounding puerperal fever; indeed, they had added to its mysterious nature. Autopsies, according to an Edinburgh practitioner in 1848, had not "as yet discovered a pathognomic mark by which to recognize the malady". ${ }^{38}$ Dissections performed on women who had died of this intra-abdominal infection presented doctors with more questions than answers. Given the inconclusive nature of their acquired information, doctors questioned the validity of performing such examinations. They expressed doubt that post-mortems would ever reveal anything of value to the understanding of puerperal fever. Although science had promised much, it had not delivered doctors from the confusion surrounding this female disease.

The controversy over autopsies may have caused at least one hospital to forbid them. ${ }^{39}$ Whether this edict reflected professional scepticism borne out of frustrating findings or a sensitivity to the implied danger to patients is unknown. Under some circumstance, though, evidence suggested that patients of doctors who performed autopsies fell victim to puerperal fever. William Campbell, an Edinburgh surgeon, wrote in 1831, that if a practitioner is "engaged in the dissection of bodies, . . . I have strong reasons for believing he may be the means of propagating [puerperal fever]." 40 This accusation was quickly challenged. John Roberton, an influential authority on obstetrics and a social activist, took the opportunity in 1832 to remind readers that persons not involved in post-mortem examinations also presented a risk

as This episode from the history of medicine is told in Winslow, op. cit., note 1 above, pp. 145-153.

${ }^{36}$ Quoted in John Roberton, 'Is puerperal fever infectious?', Boston med. surg. J., 1832, 6: 92-95, p. 92. See also, J. Symonds, 'Puerperal fever', Lancet, 1845, i: 553-554; John Armstrong, Lectures on the elements of pathology, London, Edward Portwine, 1838, p. 348.

'7 Ramsbotham, op. cit., note 28 above, p. 133.

28 Peddie, op. cit., note 26 above, p. 89.

" Boddy, op. cit., note 10 above, p. 347.

40 Quoted in Roberton, op. cit., note 36 above, p. 92. 


\section{British medical profession and contagion theory: puerperal fever 1830-1860}

to female patients. He noted that in a one-month period, a female midwife at the Manchester Lying-in Charity had delivered thirty women. Of these thirty women, sixteen had died of puerperal fever. This fifty per cent mortality rate could in no way be traced to the transmission of any "necropsical" substance. The disease had appeared only among the midwife's patients, and Roberton concluded that she "was the medium of communicating the malady".41 By the early 1840s, the avoidance of autopsies as a means of preventing puerperal fever was considered a legitimate, though not always successful, precaution. ${ }^{42}$

The need to prevent puerperal fever was heightened by an increasing awareness that standard therapeutic responses had proved inadequate to arrest the disease. Practitioners continued to treat symptoms even in a well-defined disease such as tuberculosis. Childbed women suffered, as did all other patients, from the treatments administered by well-meaning doctors whose impoverished materia medica led them to extreme "cures". ${ }^{43}$ Disagreement over the nature of puerperal fever did not preclude basic agreement over treatment. An "Anticontagionist" stated that unless feverish women were "hit hard and hit early" with bleeding and purging they would surely die. ${ }^{44}$ A "contagionist" agreed. He added the caveat that a "trickle" of blood was useless. He urged instead a "full stream" to relieve women of from eighteen to twenty-four ounces of blood.45 Anticontagionists and contagionists alike, imprisoned by their limited knowledge, routinely bled and purged their patients to no avail. Puerperal fever continued its relentless claim on female lives.

Without means to cure puerperal fever, doctors searched for methods which they hoped would prevent it. Aware by the 1840s that all persons involved in obstetrical practice could spread deadly miasmatic influences from woman to woman, practitioners tried to destroy the effluvia. In 1843, for instance, after his last four obstetrical patients had died of puerperal fever, N. B. Fisher, a small-town surgeon, "attended most reluctantly" a fifth woman. To assuage his apprehension, he changed his clothing and "washed his hands in a strong solution of chlorinated lime". His patient died. Unable to "trace [any] connection . . . beyond [himself]", Fisher admitted that he "unhappily carried the deadly poison" to every one of the victims. ${ }^{46}$

11 Ibid., p. 93.

42 This may be one reason for the negative response to Semmelweis' theory. Experience had shown that even though doctors conscientiously avoided the cadaver, their obstetric patients continued to die. Semmelweis' dogged insistence that cadaveric poisoning was the only cause of puerperal fever met with understandable rejection from doctors who knew otherwise.

4s Feminist historians have recently suggested that male physicians had a real enmity toward their female patients which influenced their advice to and treatment of women. See, for example, Carroll Smith-Rosenberg and Charles E. Rosenberg. 'The female animal: medical and biological views of women in nineteenth-century America', J. Am. Hist., 1973, 60: 131-154; Ann Douglas Wood, "The fashionable diseases": women's complaints and their treatment in nineteenth-century America', J. interdisc. Hist., 1973, 4: 25-52. For a more balanced analysis of the nineteenth-century physician and his treatment of female patients, see Regina Markell Morantz, 'The lady and her physician', in Mary Hartman and Lois W. Banner (editors), Clio's consciousness raised: new perspectives on the history of women, New York, Harper \& Row, 1973, pp. 38-53. See also my rejoinder to the feminist interpretation, 'Equal treatment for all: American medical remedies for male sexual problems, 1850-1900', J. Hist. Med., 1977, 33: 55-71.

" Robert Gooch, A practical compendium of midwifery, 3rd Am. ed., Philadelphia, Haswell, Barrington \& Haswell, 1840, p. 273.

45 Ramsbotham, op. cit., note 28 above, p. 133.

46 Fisher, op. cit., note 21 above, pp. 87, 92-93. 


\section{Gail Pat Parsons}

Lime, according to an eminent historian of medicine, "had long been a favorite weapon against miasmata" since its introduction in the late eighteenth century by Antoine-Germaine Labarrque (1777-1850) who advocated its use as a wound disinfectant. ${ }^{47}$ Given the ignorance surrounding the process of infection, chlorine was valued more for its deodorizing effects. Its use reflected the ancient idea that if an "evil smell caused sickness, a pleasant one would remove it". ${ }^{48} \mathrm{~A}$ full body bath in chlorinated solutions could not have prevented the contamination of a patient if the attendant happened to have a mild respiratory infection. The onset of a "sore throat" meant nothing to doctors unaware of living germs and droplet infection. Nor did washing their hands in chlorinated water affect pathogens present in a woman's vaginal flora. Women continued to die in unsanitary hospitals and in the supposed safety of their own homes regardless of precautions taken. ${ }^{40}$ In despair, many doctors removed themselves from obstetrical practice. They saw no other way to prevent themselves from "carrying into the [lying-in] chamber the dormant seeds of puerperal infection". ${ }^{50}$ By 1843 , the "great majority" of writers agreed that puerperal fever was a contagious disease. ${ }^{51}$

Between the years 1830 and 1860 , references to the apparent contagiousness of puerperal fever increasingly emphasized the attending physician's carrier role. For various reasons, many practitioners categorically rejected this assertion. Yet, many doctors who either denied that puerperal fever was contagious or, admitting that, believed themselves "innocent" of transmitting it, urged their colleagues to take certain personal precautions before attending pregnant women. Robert Gooch, for example, noted for his textbook on female disease, vigorously denied that he had ever communicated the disease to his female patients. He admitted his concern by encouraging practitioners to follow his example of keeping one specific set of clothing for "visiting . . . contaminated patients". ${ }^{52}$ Regardless of their stand on the issue of contagion, the spectre of physician responsibility once raised demanded a response.

Prior to the recognition of their probable involvement in the spread of the disease, doctors directed their preventive efforts toward the inanimate environment of disease. After an epidemic among lying-in women, hospital wards, for instance, were scrubbed with lime while linens were exposed to the effects of chlorine gases. ${ }^{53}$ Such

${ }^{47}$ Mettler, op. cit., note 14 above, pp. 895-896.

48 See the excellent essay by Owsei Temkin, 'An historical analysis of infection', in Studies in intellectual history, Baltimore, Md., Johns Hopkins University Press, 1953, pp. 123-147, p. 132.

10 The most recent example of a feminist interpretation of the nineteenth-century medical practitioner has just appeared. Patricia Branca writes that even though doctors had the necessary knowledge to prevent the spread of puerperal fever and, therefore, could have prevented the deaths of many women, they were simply too "busy" to wash their hands or change their clothing. Branca is apparently under the illusion that these measures would have prevented infection. She implies that doctors deliberately let thousands of women die in agony (Silent sisterhood: middle class women in the Victorian home, Pittsburgh, Carnegie Mellon University Press, 1976, pp. 86-89). Based on my own research I vigorously disagree with Branca's assertions.

${ }^{50}$ Ramsbotham, op. cit., note 28 above, p. 136.

${ }^{61}$ Fisher, op. cit., note 21 above, p. 93 ; Beecroft, op. cit., note 29 above, p. 684; Gibson, op. cit., note 10 above, p. 123; 'Notice of the London Medical Society', Lancet, 1843, i: 879.

s2 Gooch, op. cit., note 44 above, p. 270. See also Ramsbotham, op. cit., note 28 above, p. 136; Blackmore, op. cit., note 10 above, p. 176.

ss Robert Collins, A practical treatise on midwifery and diseases of women and children, New York Bailliere Brothers, 1859, pp. 191-192. 


\section{British medical profession and contagion theory: puerperal fever 1830-1860}

measures, doctors hoped, counteracted any lingering miasmatic influences. The isolated physician who battled with puerperal fever within the confines of his own practice began to focus his attention not on the patient's surroundings but on himself. With these first primitive precautions of changing their coats, sprinkling chloride of lime on their clothing, washing their hands in chlorinated solutions, and even abandoning their obstetrical patients, the isolated, now obscure, practitioners represented the cutting edge of changing medical practice.

Changing behaviour of a sub-group within a profession does not represent a "revolution". It does represent an assault on established orthodoxy. The isolated practitioner, because of his opinion that puerperal fever was contagious, implicitly warned the unconvinced that their assumptions about the disease were not only erroneous but deadly. A groundswell of troubled doctors actively encouraged their colleagues to modify their behaviour. Even as men of "high authority" rejected the underlying premise of such pleas, now-forgotten figures exercized precautions. The limited success of their primitive measures only affirmed their conviction that they were involved in the spread of a lethal disease. ${ }^{54}$

This is not to imply that "contagionism" dominated the profession or even that every physician conceded that puerperal fever was contagious. There is not now nor should we expect to find in the past a unanimous opinion on the cause of disease. Anticontagionists, contagionists, and so-called contingent-contagionists co-existed within the profession. Indeed, a single practitioner could defend any one of the three theories depending on which disease commanded his attention. He could conceivably deny the contagiousness of cholera while admitting his responsibility for transmitting puerperal fever to a childbed woman, a poignant acceptance of contagion.

By concentration on dramatic pandemics, the subtle complexities of nineteenthcentury medical practice have been obscured. Cholera, yellow fever, and the plague instantly appeared and just as quickly disappeared. They claimed victims at random, regardless of age, race, class, or sex. Tracing communication from person to person within large, mobile populations proved difficult, and doctors attributed the disease to atmospheric causes. Historians have concluded, therefore, that "anticontagionism" permeated the profession. Such an assessment is correct for those diseases surveyed. It is not an accurate appraisal of professional attitudes toward all diseases. An epidemic of puerperal fever could be traced because of the peculiar state of those exposed to its attack; that is, immobilized, pregnant women. Out of this unique circumstance, a "grass roots" contagionist movement materialized.

Hospital epidemics of puerperal fever had offered practitioners a measure of anonymity. While losses in private practice paled in comparison to the devastating mortality rates among hospitalized women, it was the isolated practitioner who spoke most forcibly about the contagiousness of puerperal fever. After losing nearly every woman he delivered, the lone doctor could not help but be struck that patients of colleagues no more competent nor careful than he escaped the disease. Many of

54 Thomas S. Kuhn, The structure of scientific revolutions, 2nd ed., Chicago, University of Chicago Press, 1970, especially pp. 64-65. Recognition of themselves as carriers certainly presented doctors with something of an anomaly. Contagious diseases, according to the prevailing "paradigm", were thought to reproduce themselves; however, based on experience, puerperal fever was somehow produced by erysipelas after women had been exposed to the latter disease via their physician. 


\section{Gail Pat Parsons}

these now-forgotten doctors openly admitted their role in the spread of this disease and accepted the burden of being responsible for the deaths of their patients. Given the low esteem in which medicine was held at the time, such admissions are not without a heroic quality.

Men of "high authority" rejected the notion of contagion for a variety of socioeconomic, political, and medical reasons. Generalizing about medical attitudes from the writings of an élite only reveals their assumptions. The history of medicine must reflect the complexity of its subjects, the men and women who practised medicine. In 1965, Erwin H. Ackerknecht spoke eloquently about this need. He urged historians to study what all doctors did, not merely what an élite said..$^{55}$ This study has attempted to respond to that plea. By emphasizing, for the most part, the ordinary physician and his battle with a common disease, this study has revealed that contagion theory was in anything but a moribund state. Those doctors practising obstetrics, at immeasurable personal and professional costs, kept alive the issue of contagion during the first half of the nineteenth century. ${ }^{56}$

\section{SUMMARY}

Epidemic puerperal fever haunted British practitioners throughout the nineteenth century. Outbreaks of it in hospitals as well as in private practices provoked members of the medical profession engaged in obstetrical work into a sustained discussion of contagion. In the ensuing exchange, physicians confronted the likelihood that they transmitted the disease. Although they did not know exactly with what or exactly how they infected their female patients, many doctors advocated personal cleanliness and crude disinfecting procedures as precautionary measures. Personal experiences and prebacteriological theories of contagion influenced the behaviour of physicians who cared for parturient women. By showing that a group of concerned practitioners within the profession believed in contagion and, further, changed their behaviour because of that conviction, this paper does not confirm the widely accepted opinion of historians that anticontagionist sentiment characterized medical thought and practice in the first half of the nineteenth century.

\section{ACKNOWLEDGEMENTS}

The author would like to thank Dr. Robert C. Powell, Professors Richard D. McKinzie and Stanley B. Parsons, University of Missouri-Kansas City, Kansas City, Missouri, and Dr. Robert P. Hudson, University of Kansas Medical Center, Kansas City, Kansas, for their helpful criticisms and comments on this paper.

${ }^{35}$ Erwin H. Ackerknecht, 'A plea for a "behaviorist" approach in writing the history of medicine', J. Hist. Med., 1967, 22: 211-214.

st Other historians have made passing reference to the recognition by practitioners of the contagiousness of puerperal fever. See, for example, James V. Ricci, One hundred years of gynecology, Philadelphia, Blakiston Company, 1945; Malkin, op. cit., note 12 above, p. 61.

I am presently at work on this same topic as it took shape in America between the years 1830 to 1860. (Unpublished paper presented at the American Association for the History of Medicine, Madison, Wisconsin, May 1977.) 